\title{
GOT2 Gene
}

National Cancer Institute

\section{Source}

National Cancer Institute. GOT2 Gene. NCI Thesaurus. Code C38501.

This gene is involved in the tricarboxylic acid cycle, urea cycle and amino acid metabolism. 